\title{
Eurasian eagle owl (Bubo bubo) colonizing lowland floodplain forests in south Moravia (Czech Republic) and cases of its breeding in wooden nestboxes

\author{
Osídlování lužních lesư na jižní Moravě výrem velkým (Bubo bubo) a př́pady jeho
} hnízdění v dřevěných budkách
}

\section{David HORAL \& Vlasta ŠKORPÍKOVÁ}

\begin{abstract}
This paper presents data on the occurrence and breeding of Eurasian eagle owl (Bubo bubo) in south Moravia, Czech Republic (Břeclav and Znojmo districts), in the floodplains of the Morava and Dyje Rivers, since 1994, and the first cases of confirmed breeding from 2009 to 2011. In two cases, eagle owls bred successfully in large, wooden artificial nestboxes originally installed for saker falcon (Falco cherrug).

Abstrakt: Článek shrnuje údaje o výskytu a hnízdění výra velkého (Bubo bubo) v oblasti lužních lesů jižní Moravy v nivách řek Moravy a Dyje (okresy Břeclav a Znojmo) od r. 1994 a první př́pady prokázaných hnízdění v těchto biotopech v letech 2009-2011. Ve dvou př́ípadech výři úspěšně vyhnízdili ve velkých dřevěných budkách, původně určených pro raroha velkého (Falco cherrug).
\end{abstract}

Key words: unusual breeding, Břeclav and Znojmo districts

David Horal, Agency for Nature Conservation and Landscape Protection of the Czech Republic, regional centre Brno, Kotlářská 51, CZ-602 00 Brno, Czech Republic. E-mail: david.horal@seznam.cz.

Vlasta Škorpíková, Lukov 44, CZ-669 02 Znojmo, Czech Republic. E-mail: vlasta_skorpikova@volny.cz.

\section{Introduction}

The Eurasian eagle owl (Bubo bubo) colonized lowland forests in the floodplain of the Danube (Donau, Dunaj), March (Morava) and Thaya (Dyje) Rivers in the early 1990s (Zuna-Kratky 2000). Further data from lowlands in SW Slovakia including the March floodplain, were compiled by Noga (2005). Similar trends were also reported from other regions e. g. eastern Slovakia (Hrtan 2010, Mihók \& Lipták 2010).

\section{Observation and discussion}

Apart from the finding of a shot eagle owl on October 11, 1994, near the village of Lanžhot (P. Horák in Zuna-Kratky et al. 1994), the first records from the Czech side of the March and Thaya Rivers confluence (Břeclav district) come from 2008 when one individual was observed on March 21 and pellets were found at three localities in March and April (D. Horal = DH). Pellets found on April 22 contained the following prey species: common vole (Microtus arvalis) - 4, field mouse (Apodemus sp.) - 1, water vole (Arvicola amphibius) - 1 and common blackbird (Turdus merula) - 1 (det. J. Thelenová). From autumn 2008 until spring 2009, one calling male (on one occasion even a mated pair) was regularly heard (DH) and the species was observed at two more localities by local foresters and hunters (R. Hrnčíř in verb.). On April 4, DH found an incubating eagle owl in a nestbox intended for saker falcon (Falco cherrug). This large wooden nestbox of approx. 75 (width) $\times 50$ (depth) $\times 50$ (height) $\mathrm{cm}$, was placed in an ash tree (Fraxinus sp.) at a height of ca $25 \mathrm{~m}$. Sakers successfully bred in it in 2006 and 2008. On May 1, 2009, two owlets ca. 2-3 weeks old were in the box. On the same day, the roosting tree (presumably of the male) was found $50 \mathrm{~m}$ from the nest. It was a low field maple (Acer campestre) with dense branches reaching down to the ground, with many pellets below it. On May 23, an adult male eagle owl (wing length $434 \mathrm{~mm}$, tarsus $75 \mathrm{~mm}$ ) was found dead in a forest channel $190 \mathrm{~m}$ from the nest. The cause of death was not known but the bird had not been shot. Both young fledged successfully in June, so the female obviously managed the feeding and parental care duties on her own. Prey remains below the nestbox contained mainly hedgehogs (Erinaceus sp.) and mallards (Anas platyrhynchos). In 2010, breeding was not confirmed but one calling male was heard on May 1 at the same locality. 


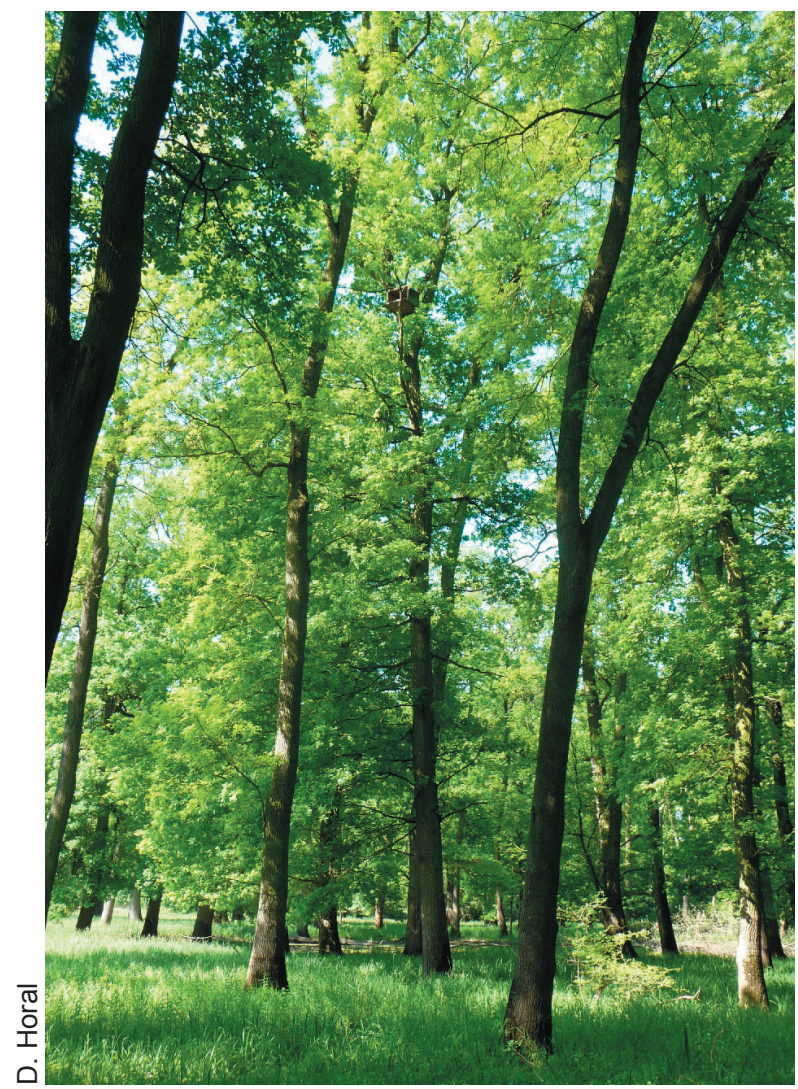

Fig. 1. The nest site of eagle owl with the nestbox in 2011.

Obr. 1. Hnízdiště výra velkého v roce 2011 s hnízdní budkou.

In the winter 2008/2009, an new eagle owl was recorded at another locality ca. $2.4 \mathrm{~km}$ south of the previous one (R. Hrnčír in verb.) when a bird was flushed from the same type of nestbox, on an oak tree (Quercus robur) placed at about the same height. Later, one bird was repeatedly observed at this locality (roosting on trees or on the ground): 2009 - May 23, June 25, September 29 and October 3. On March 24, 2011, an incubating owl was observed in the box. On April 22, one chick, ca. three weeks old, was present. On May 10, the successfully reared owlet was seen roosting on a branch ca $3 \mathrm{~m}$ below the nestbox. One of adult birds was also present near the nest, mobbed by three hooded crows (Corvus cornix). Remains of long-eared owl (Asio otus) were found below the tree.

In 2009-2011, eagle owls were recorded at two or three more localities within the same forest (ca. $4500 \mathrm{ha}$ ) according to observations, calls, pellets etc. This, along with new data from the Austrian side of the floodplain (e. g. two cases of confirmed breeding in 2011 - one in an old black stork (Ciconia nigra) nest and one in an old

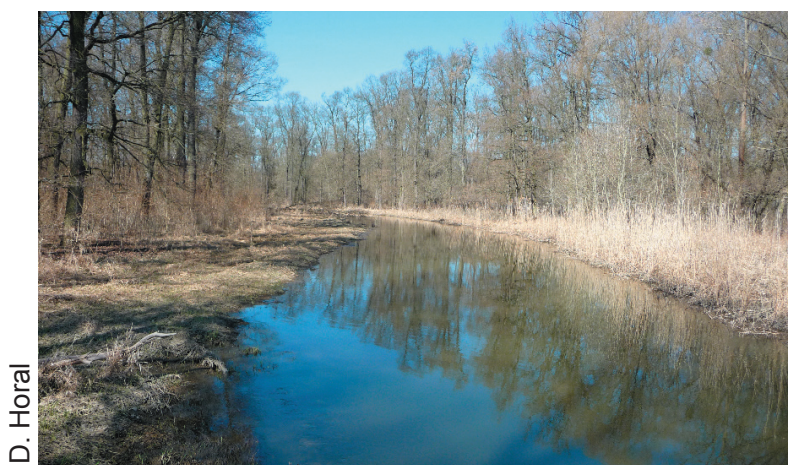

Fig. 2. The nestsite of eagle owl in 2009.

Obr. 2. Hnízdiště výra velkého v roce 2009.

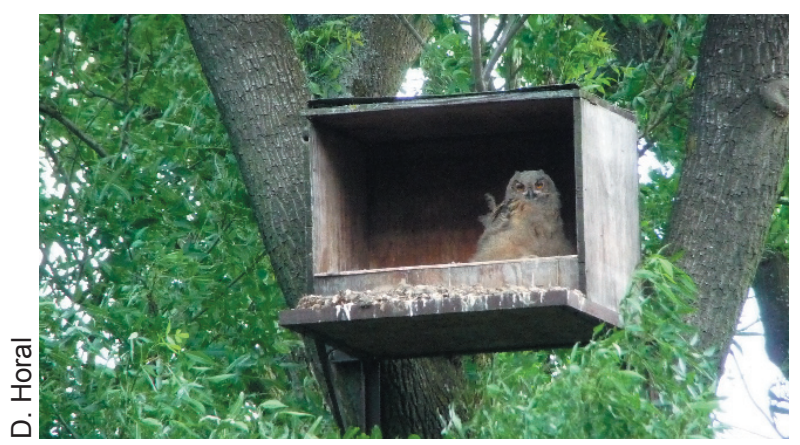

Fig. 3. Eagle owl young in the nestbox, June 12, 2009 (the second young was already outside the nestbox).

Obr. 3. Mládě výra velkého v budce, 12. červen 2009 (druhé mládě $v$ tu dobu již bylo mimo budku).

raptor nest (T. Zuna-Kratky and M. Bierbaumer in litt.), suggests that this new "floodplain forest population" had already been established. The altitude of this breeding area is $150-155 \mathrm{~m}$.

The breeding of eagle owls in a wooden nestbox intended for sakers - probably the first documented case - was described by Mihók \& Lipták (2010); in this case, the box was installed on a high-voltage pylon. At the same period, eagle owls also started to colonize the floodplain of the Thaya (Dyje) River upstream in the Znojmo district, ca $40 \mathrm{~km}$ west of the above described area. The Austrian side of this area is known as Laaer Becken. The first records from this region, stretching from the city of Znojmo to Drnholec, came from Ječmenišš (south of the village of Vrbovec near the Czech-Austrian border, ca. $220 \mathrm{~m}$ a. s. 1.), in the winter: one dead individual was found on February 26, 1994 (P. Horák in litt.); one eagle owl sitting in a loess wall, traditionally occupied by a pair of little owls (Athene noctua) and European bee-aeters (Merops apiaster), was recorded on February 18, 2005; 
one individual hid in a willow tree on December 18 and 22, 2005 (V. Škorpíková = VŠ).

This locality apparently could not meet the demands of the species for breeding, but its spreading along the Thaya River continued as one individual was flushed from riverine growth near Dyjákovice (184 m a. s. 1.) on January 12, 2007 (V. Prášek in verb.). In the following spring, on March 8, 2008, a fresh pellet of the species was found on the bank of the Černá strouha stream in Lužný les forest north of Dyjákovice, $200 \mathrm{~m}$ a. s. 1. (VŠ) - this locality seems to be suitable for the species, but breeding has not yet been confirmed).

At the same time, hunters from the Hrabětice-Hrušovany nad Jevišovkou region reported a calling male at Trávní dvưr, $180 \mathrm{~m}$ a. s. 1. (this wetland consists partly of old floodplain forests, some of the most valuable natural areas in the Znojmo region). On March 4, 2010, an eagle owl was flushed in the northern part of this area (VŠ), and at the same place, both authors recorded a pair on February 11, 2011: first we heared a call of the male at $15: 15$, later we observed ears of the female sitting in an old nest of white-tailed eagle (Haliaeetus albicilla) high in an oak tree. Finally, about $300 \mathrm{~m}$ from the nest in an old growth woodland with a nest of black stork, we flushed the male from his roosting place (a dense box elder maple Acer negundo with dry clusters of seeds) - according to the amount of droppings and pellets on the ground below, the site had been used for some time. The nest was not checked later in the season.

In 2011, another locality in the lowlands in the vicinity of Znojmo occupied by eagle owl was found (VŠ). On April 29, a bird sitting in an old northern goshawk (Accipiter gentilis) nest in a white poplar (Populus alba) was found. The tree is situated in ca 80-years-old growth woodland in the Jevišovka River floodplain near the village of České Kř́dlovice, $190 \mathrm{~m}$ a. s. 1 . (ca $14 \mathrm{~km}$ north-west of the nest in Trávní dvůr locality). On May 9, the female was still incubating (VŠ, Z. Tunka), the nest was not checked later. Thanks to the regular monitoring of diurnal raptor nests in this region, it is almost sure that this locality was not occupied by eagle owls prior to 2011. Even the most recent Czech ornithological literature (Hora et al. 2010) mentions the species as absent from the lowlands of south Moravia. Obviously, we are witnessing the colonization of a new breeding area and new habitats, the so far unoccupied floodplain forests.

\section{References}

Hora J, Brinke T, Vojtěchovská E, Hanzal V \& Kučera $Z$ (eds) 2010: Monitoring druhů př́lohy I směrnice o ptácích a ptačích oblastí v letech 2005-2007 [The monitoring of the Birds Directive Annex I species and SPAs in 2005-2007]. AOPK ČR. Praha, 320. [In Czech with English summary]

Hrtan E 2010: The nesting of the Eurasian eagle-owl (Bubo bubo) in a man-made building. Slovak Raptor Journal 4: 103-104. DOI: 10.2478/v10262-0120051-1.

Mihók J \& Lipták J 2010: Eurasian eagle-owl (Bubo bubo) nesting in a nest box on a very high voltage elektricity pylon. Slovak Raptor Journal 4: 99-101. DOI: 10.2478/v10262-012-0049-8.

Noga M 2005: Výr skalný (Bubo bubo) na nížine [Eagle owl (Bubo bubo) in the lowlands]. Dravce a sovy 1(1): 16-17. [In Slovak]

Zuna-Kratky T 2000: Eagle owl (Bubo bubo) breeding in the lowland floodplain-forests in northeastern Austria. Crex 20: 43-47.

Zuna-Kratky T, Kalivodová E, Kürthy A, Horal D \& Horák P 2000: Die Vögel der March-Thaya-Auen im österreichisch-slowakisch-tschechischen Grenzraum. Distelverein. Deutsch Wagram, 285. 